These latter are arranged in an elaborate hierarchy of angelic, daemonic and heroic, human and finally irrational levels, all dependent on their proper divine henad, in the sense of being in its seira, or chain. The distinction of these levels of being, and of those in the realm of Nous, is relevant to the protracted discussions of Books III and IV of the Parmenides Commentary of the various levels at which the Forms manifest themselves. For the details see the introductions to those books. Proclus, of course, adopts the Platonic Theory of Ideas in the form in which it was bequeathed to him, of which he gives us a useful account at the beginning of Book IV (837-853).

Other than this, Proclus' views on the lower levels of Being, Soul, Nature, and Matter, and the multifarious beings contained in them, are not relevant to a study of the Parmenides Commentary, which is concerned only with the henadic and noetic realms. Soul and Nature are more the concern of the Timaeus Commentary. A description of them would, I think, unnecessarily lengthen this survey. Readers anxious for more detail should turn to Beutler's excellent $R E$ article, "Proklos," to which I am much indebted in this brief account.

Discussions of particular aspects of Proclus' philosophy relevant to the Parmenides Commentary may be found in the introductions to individual books. I would draw attention here to the following: in Book I, his allegorical method (pp. 5-7); in Book II, the structure of the realm of Forms (pp. 94-98); in Book III, arguments for the existence and nature of Forms- "Of what things are there Forms?" (pp. 145-156); in Book IV, participation of particulars in Forms, together with discussion of various levels of Form (pp. 195-209); in Book V, dialectic, and in particular "Parmenidean" dialectic (pp. 326-331); in Book VI, the number and subject matter of the hypotheses of the Parmenides, involving a conspectus of the structure of Proclus' universe and those of his predecessors (pp. 385-390); and in Book VII, the detailed structure of the hypostasis of Nous-a subject more proper to a commentary on the Second Hypothesis, but appropriate (negatively) here (pp. 474491). It can be seen from this survey how the Parmenides and the Timaeus (which is concerned with the Soul and all below it) could be taken by Neoplatonists to cover, complementarily, the whole gamut of existence.

\title{
B. PREVIOUS COMMENTARY ON \\ THE PARMENIDES
}

Proclus himself, in the Preface to the Commentary (630.15-645.8) gives a schematic account of the history of the interpretation of the Par- 


\section{GENERAL INTRODUCTION}

menides which there is no reason to contradict. He does not present it as a chronological succession, but it is easily understood as such. ${ }^{9}$

The earliest interpretation of the dialogue ${ }^{10}$ was that it was a logical exercise with a polemical purpose, in effect a satire on the Zenonian method of argument, to be compared in this to the parody on Protagoras' doctrine in the Theaetetus. This interpretation is distinguished from one, which we find represented in Albinus (Isagoge, ch. 3; Didaskalikos, ch. 6); and Thrasyllus (ap. Diog. Lacrt. III, 58), which regards it as a logical excrcise with a positive, educational purpose. It is possible, therefore, that the first interpretation was that of the New Academy, who would have found the Parmenides, on thcir interprctation, a most useful document for teaching the art of destructive argument, even as they found the Theaetetus a useful source document for a skeptical theory of knowledge. " But there is no question of any New Academic writing a commentary on the dialogue.

When the Platonic School returned to dogmatism with Antiochus, interpretation of the Parmenides must have altered. The first part would now be seen, not as a demolition of the Theory of Ideas, but simply as a purification of it from naive misinterpretations, while the second part was certainly seen as an exercise in logical method, very much as Parmenides himself advertises it in the dialogue. Thus Albinus in Didaskalikos, chapter 6, finds examples of various Aristotelian categorical syllogistic figures in Parmenides' arguments (e.g. the second at 145b, while the third he appears to extract from the second hypothesis as a whole, ${ }^{12}$ as well as various hypothetical and "mixed" syllogisms (e.g. at $137 \mathrm{dff} ., 145 \mathrm{bff} ., 145 \mathrm{a}$ ). Taurus uses $156 \mathrm{~d}$ as the basis for a discussion of the notion of 'instant' (Aulus Gellius, NA VII, 13).

A mong mainline Middle Platonists, then, there is no indication that anyone saw the second part of the dialogue as containing any positive metaphysical doctrine. But on the fringes of the Platonic movement it is possible that some people did. E. R. Dodds, in an important article, ${ }^{13}$ argues that the elaborate structure of reality of the Neopythagorean

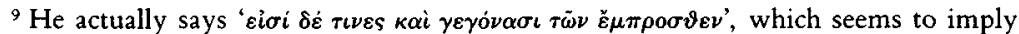
that he is envisaging contemporary differences of opinion also, though I find it unlikely that there were still partisans of the "logical" interpretation in Proclus' Academy.

${ }^{10}$ I have summarised these views in the introduction to Book I. Here I will merely discuss their possible identity.

11 This we can gather from a remark in the Anon. Theaet. Comm. 54.38ff, that passages such as $150 \mathrm{cff}$. proved, for some people, that Plato was an Academic, since he never dogmatises! See on this John Glucker, Antiochus and the Late Academy, pp. 38-41.

12 "That which partakes in shape is; qualified; that which partakes in shape is limited: therefore, what is qualified is limited" does not correspond to any particular argument in the dialogue.

${ }_{13}$ "The Parmenides of Plato and the Origin of the Neoplatonic 'One'," CQ 22(1928): 129-142.
} 
Moderatus (1st cent. A.D. $)^{14}$-or rather, that attributed by Moderatus to Plato-is based upon a metaphysical interpretation of the second part of the Parmenides. The relevant passage is as follows: ${ }^{15}$

It seems that this opinion concerning Matter was held first among Greeks by the Pythagoreans, and after them by Plato, as indeed Moderatus tells us. For he (sc. Plato), following the Pythagoreans, declares that the first One is above Being and all essence, while the second One-which is the truly existent (ontos on) and the object of intellection (noêton) - he says is the Forms; the third, which is the soul-realm ( $p$ sychikon), participates (metechei) in The One and the Forms, while the lowest nature which comes after it, that of the sense-realm, does not even participate, but receives order by reflection from those others, . . .

Dodds' proposal that this rests on an exegesis of the Parmenides is most persuasive. The "three kings" of the Second Letter (312e) might be seen as playing their part as well, but that curious document may itself be dependent on a metaphysical interpretation of the Parmenides. In this scheme, the First Hypothesis concerns a supra-essential One; the Second, a "One-that-is," or Nous; and the Third, Soul. It may even be that the Fourth is being asserted to concern Nature, or the physical world, but that is not so clear.

If Moderatus is being influenced by any previous authority here, that is not apparent to us. Nor does there seem to be any sign of such an interpretation of the Parmenides among "orthodox" Platonists before Plotinus (though Numenius and/or Ammonius Saccas may well have been influenced by it). ${ }^{16}$ However, unless one wishes to deny this passage to Moderatus altogether, it seems to me that Dodds' elucidation of it is valid, and that we have here an indication of a metaphysical exegesis of the dialogue flourishing at least in the Neopythagorean tradition.

This Neopythagorean interpretation of the dialogue, on the other hand, does not seem to concord with the first of the "metaphysical" interpretations listed by Proclus (Book I, 635.31-638.2). This interpretation, he says, takes the subject of the dialogue as Being, as in Parmenides' poem. As I suggest in the introduction to Book I, this can

\footnotetext{
${ }^{14}$ Relayed to us, via Porphyry, by Simplicius, In Phys. 230.34ff. Diels.

15 The passage is from a treatise of Porphyry's On Matter, so that is his primary concern here.

${ }^{16}$ Porphyry, in his Life of Plotinus (20) quotes Longinus as saying that Numenius, Cronius, Moderatus, and Thrasyllus wrote on the first principles of Plato and Pythagoras, though "falling far short of Plotinus in precision and fullness." Dr. Harold Tarrant suggests to me that this may betoken a metaphysical exegesis of the Parmenides by these authors, but it is really not much to go on.
} 
hardly apply to anyone after Plotinus, and since it does not apply to Moderatus, one is left with the rather desperate suggestion that Plotinus' contemporary, Origen the Platonist, is intended, a man of whose views Proclus takes some cognisance, presumably because Porphyry did so.

The first Platonist to adopt unequivocally the "metaphysical" interpretation of the Parmenides is Plotinus. Plotinus does not, of course, write commentaries as such, but his programmatic treatise Enn. V, 1, "On the Three Principal Hypostases," becomes, in effect, from chapter 8 on, an exegesis of the latter part of the Parmenides, particularly of the First Hypothesis. Interestingly enough, Plotinus leads into this exegesis with a reference to the Three Kings of the Second Letter. In presenting this exegesis, which takes the One of the First Hypothesis to be the One above Being, that of the Second to be Intellect, and that of the Third to be Soul, Plotinus shows consciousness of presenting a new departure (while defiantly maintaining his accord with the most ancient and best authorities) when he says (8.9-14): "These teachings, then, are no novelties, no inventions of today, but long since stated, though not straightforwardly; our doctrine here is an exegesis of those earlier ones, and can show the antiquity of those opinions on the testimony of Plato himself" (MacKenna's trans., slightly emended). This will at least imply that he feels himself to be going against the consensus of mainline Platonism, though not necessarily against Ammonius, or even Numenius.

Plotinus' senior pupil, Amelius, at least had views on the subject matter of the hypotheses, as we learn from Proclus' doxography ${ }^{17}$ in Book VI (1052.31-1053.35). I will not go through the scheme in detail, except to note that Amelius, as one might expect, follows Plotinus in his identification of the subjects of the first three hypotheses, though he goes on to find subjects for all the rest as well (eight, on his calculation).

There is no need to suppose, however, that Amelius wrote a commentary on the Parmenides as such (we know nothing of his views on any other aspect of it, unless one counts his doctrine that there were Forms of Evils). With Porphyry, on the other hand, the situation is rather complex. It is fairly plain, from his probable position in a series of anonymous doxographies (see below, p. xxxi) that he wrote a commentary on the dialogue, but doubt still surrounds the attribution to him of the Anonymous Turin Commentary, boldly claimed for him by the French scholar Pierre Hadot. ${ }^{18}$ Hadot brings much learning to bear

\footnotetext{
${ }_{17}$ The doxography is anonymous, like everything else in the commentary, but all the figures concerned are identified by an industrious scholiast.

18 "Fragments d'un Commentaire de Porphyre sur la Parménide," Revue des Études Grecques LXXIV (1961): 410-438, and Porphyre et Victorinus, vol. II.
} 
on the question, but the parallels that he adduces still, I think, create no more than a probability. The Anonymous Commentary covers the text, in patches, from $137 \mathrm{c}$ to $143 \mathrm{a}$, so that much of it coincides with the surviving part of Proclus' Commentary. It is therefore interesting to compare them where they can be compared.

The first point of contact comes at Anon. 1, 25ff. Hadot, where the author is discussing the proper sense in which the One may be described as $\ddot{\alpha} \pi \varepsilon \iota \rho \circ \nu$ (137d7). After rejecting the view of Speusippus and another authority whose name is corrupt that it is infinite in smallness ( $\delta i \dot{\alpha} \sigma \mu \iota \kappa \rho \dot{\tau} \tau \eta \tau \alpha)$, the author advances his own view that it is so because of its infinite power, and its being the cause of all existing things, and first principle of ali things that follow upon it . . . and because it transcends even the notion of 'one' ( $\delta \iota \dot{\alpha} \tau \dot{o} \alpha \dot{v} \tau \grave{\eta} \nu \kappa \alpha \tau \alpha \lambda \varepsilon i \pi \varepsilon \iota \nu \kappa \alpha \grave{\iota} \tau \grave{\eta} \nu$

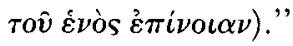

Now this view does indeed appear in Proclus, as Hadot points out, at 1118.19ff., in the course of a doxography on just this question. But there are complications. This view appears second in a list of four, culminating in that of Syrianus and Proclus. Working backwards, we find a view, probably that of Iamblichus, that the One is infinite because Nous is Limit, and it transcends Nous. Then comes the view that it is

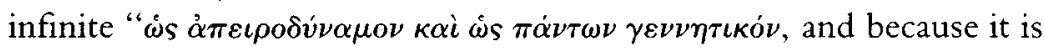
the cause of unlimitness in all existent things, and extends the gift of itself throughout all existent things." The first view given is that the One is infinite because it is intraversable $(\dot{\alpha} \delta \varepsilon \varepsilon \xi i \tau \eta \tau o \nu)$ and because it serves as a limit to all other things, while requiring no limit itself. Now this first view is also criticised by Plotinus in Enn. VI, 9.6, who then proceeds to adopt the second view listed here: "We must therefore hold that the One is infinite not by reason of its intraversability either in size or in number, but rather from the infinity of its power $(\tau \tilde{\omega} \dot{\alpha} \pi \varepsilon \rho \iota \lambda \dot{\eta} \pi \tau \omega$ $\tau \tilde{\eta} s \delta \nu \nu \dot{\alpha} \mu \varepsilon \omega s) . "$

It is entirely probable that Porphyry would be in agreement with Plotinus on this. Plotinus also declares (5.3ff.) that smallness should not be regarded as being in question here, as it might be if one were discussing the mathematical point. The first view listed by Proclus is therefore pre-Plotinian, and the second view that of Porphyry. What we now observe, though, is a number of small inconsistencies between Proclus and the Anon. Proclus attributes to Porphyry (?) the view that it is infinite because it is not just the cause of existent things, but the cause of unlimitedness in all existent things (which, indeed, makes more sense). There is also no mention in Proclus of the idea that the One transcends even the notion of "One," a point made much of by the Anon. On the evidence so far, one might say that the commentary seems to be influenced by Dorphyry, but could be that of a pupil. 


\section{GENERAL INTRODUCTION}

The next point of contact, after a long gap in the text, occurs at $139 \mathrm{c}$ (sects. III-VI) on the question whether the One is other than the Others (its unlikeness to the Others is brought in too, although this is raised only at $139 \mathrm{e} 7 \mathrm{ff}$.). The text of the Anon. resumes at the point where the aporia is being raised as to whether God can in this case be said to be "other than" and "unlike to" Intellect. The answer to this is that the One (or God) does not differentiate itself from other things by unlikeness or otherness, but by possessing an "incomparable superiority" $\left.{ }_{\alpha}^{\alpha} \sigma \dot{v} \mu \beta \lambda \eta \tau o s \quad \dot{v} \pi \varepsilon \rho \chi \chi \eta^{\prime}\right)$ to everything else, in virtue of which everything else is, as it were, nothing. The author then goes on to illustrate the unsuitability of applying the terms 'other' and 'same' to the One by using the comparisons of our talk of the sun's 'rising' and 'setting', where nothing at all is in fact happening to the sun, and of our thinking the land is moving as we sail past it, while in fact it is we who are moving.

These images find no echo, unfortunately, in what should be the parallel passage of Proclus (Book VII, 1184.9-1185.10). Here, an aporia is raised, not about Intellect in particular, but "how the One can be said to be transcendent over all other things, if it is not other than them?" The answer is that the One transcends and is separate from all other things, not by virtue of Otherness, but through an "unspeakable su-

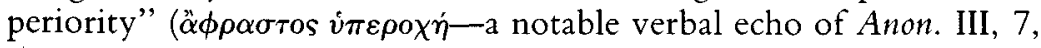
one might argue, though Hadot does not note it). Proclus, instead of either of the Anon.'s images, points to the two usages of aei-“always," to signify sempiternity, in the case of the cosmos, and eternity, in the case of Intellect. He also does not follow the Anon. in laying any emphasis on the non-existence of everything else, a topic on which the Anon. expatiates at length. Indeed, apart from the partial coincidence of phraseology in $\alpha \hat{\alpha} \phi \rho \alpha \sigma \tau o s \dot{v} \pi \varepsilon \rho o \chi \dot{\eta}$, there is no indication that Proclus is acquainted with the text of Anon.

The next point of contact occurs at 141a5-d6, the proof that the One cannot be "in time," and so neither older nor younger nor the same age as itself. This is all one lemma for the Anon., though Proclus divides it into six, covering ten pages of Cousin's text (1233.33 to 1233.19). Once again, the position is less than satisfactory. First of all, Proclus begins with a discussion of how the One should transcend eternity as well as time, which is not reflected in Anon., who turns directly to the question of the logical form of Plato's argument here.

This corresponds to Proclus' discussion from 1225.37 on (his second lemma), and both Proclus and Anon. then address the view held by some that Plato is simply being sophistical here. In answer to this, Proclus provides a three-stage doxography leading up to Syrianus (1226.2ff.), so that this would have been an excellent place to test Por- 
phyrian authorship, but unfortunately Anon.'s text breaks off just as he has stated the problem (VIII, 35). We do at least have a minimal verbal

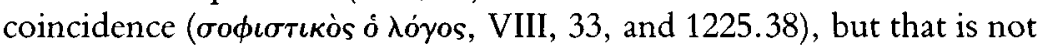
much to go on.

When the text resumes again (sects. IX-X) we are at the end of the First Hypothesis, discussing the unknowability of God, à propos, presumably, 142a3-8, but there is no point of contact between Proclus and Anon. here, and Proclus does not give a doxographical survey which would enable us to identify any Porphyrian doctrine.

After that, we are in the Second Hypothesis, and all hope of comparison ends. The confrontation between the two texts has been tantalisingly inconclusive. There are points of contact, but nothing, I think, that could not be explained by a common source in Porphyry, while nothing that is really distinctive about Anon. comes through in Proclus. But one might well make two points here. First, if this is not Porphyry, who on earth is it? It is not Iamblichus, and the pattern of Proclus' doxographical notices seems to show that the commentaries of Porphyry and Iamblichus were the only ones, apart from that of Syrianus, with which he was familiar. Occasionally there is a fourth opinion given, but this can usually be explained as someone Porphyry is refuting, and need not denote another full-scale commentator. Secondly, one might argue that Proclus might not in fact be using Porphyry's commentary at first hand, but only through Iamblichus or Syrianus. Incredible as this might seem, we should not underestimate the capacity of late antique commentators to bypass primary sources when secondary ones were available. Thus Proclus may only have been acquainted with the main points of Porphyry's exegesis and not with his literary elaborations. On the whole, I am prepared to leave the Anon. Taur. with Porphyry on the basis of the analogies which Hadot has brought to light, while being unable to share Hadot's certainty that he has solved the puzzle.

After Porphyry, we also have sufficient evidence that Iamblichus composed a commentary on the Parmenides. Apart from evidence of his views on the subject of the hypotheses (1054.35-1055.25, with the scholiast) we have about ten references to him in Damascius' De Principiis (the latter part of which we may now, following Westerink, ${ }^{19}$ learn to term his Commentary on the Parmenides), which clearly come from a Parmenides Commentary (frs. 3-14 in my collection). The extent to which he contributed to the Syrianic-Procline view of the dialogue is not clear, but he certainly will have allegorised the characters and

${ }^{19}$ Proclus, PT III, pp. lxxxiii-lxxix. It is plain, in fact, that everything from ch. 127 of the De Principiis onwards (vol. II, p. 5 Ruelle) is a commentary on the Parmenides, beginning with the Second Hypothesis (142b1). 
adopted a positive interpretation of the arguments of the first part. As regards the interpretation of the First Hypothesis, we have eleven doxographic passages in Books VI and VII, where a series of three authorities is presented, culminating in Syrianus, which leads to the probability that the previous two are Porphyry and Iamblichus. In a number of cases, it is possible to discern something, either in the content or in Proclus' way of referring to them, that is characteristic of one or the other, and I have adverted to these in the notes. Certainty can never be claimed here, but I think it likely that we have the opinions of Porphyry and Iamblichus on a series of passages, which show that they gave detailed attention to the text. However, there is no indication that Iamblichus anticipated the elaborate series of identifications of levels of being worked out by Syrianus for the First and Second Hypotheses.

I append here a list of these passages, to serve as a basis for further discussion:

\begin{tabular}{|c|c|c|}
\hline \multicolumn{3}{|c|}{$\begin{array}{c}\text { Passages Attributable to Porphyry and Iamblichus } \\
\text { From Books VI and VII }\end{array}$} \\
\hline & Porphyry & Iamblichus \\
\hline \multirow[t]{5}{*}{ VI } & $1053.38-1054.37$ & $1054.37-1055.25$ \\
\hline & $1089.30-1090.13$ & $1090.13-23$ \\
\hline & $1106.31-1107.9$ & $1107.9-1108.19$ \\
\hline & $1114.1-19$ & $1114.20-35$ \\
\hline & $1118.19-25$ & $1118.25-33$ \\
\hline \multirow[t]{6}{*}{ VII } & $1140.26-1141.13$ & $1141.13-1142.10$ \\
\hline & $1150.2-21$ & $1150.22-1151.7$ \\
\hline & $1173.7-1174.3$ & $1174.3-12$ \\
\hline & $1216.15-37$ & $1216.37-1217.13$ \\
\hline & $1226.6-15$ & $1226.15-26$ \\
\hline & $64 \mathrm{~K} .25-66 \mathrm{~K} .24$ & $66 \mathrm{~K} .25-68 \mathrm{~K} .14$ \\
\hline
\end{tabular}

The existence of commentaries by Porphyry and Iamblichus, then, is assured. As to Plutarch of Athens and Syrianus, Proclus' immediate predecessors and teachers, the position is less certain. In the case of Plutarch, we know that he had views on the Parmenides, since we have his interpretation of the subject matter of the hypotheses (of which he identified nine) in Book VI, 1058.21-1061.20, but there is no evidence that he composed a commentary on the dialogue. He does not seem to figure in the doxographical passages (where he should be accorded comparable honour to Syrianus, if he had any views), and Damascius only mentions him in connection with the identification of the subject 
matters, though he frequently records the views of Syrianus. However, Plutarch's view of the subjects of the hypotheses formed the basis for that of Syrianus, so it is important. He sees only the first five as having positive subjects (God, Intellect, Soul, Forms-in-Matter, Matter), while the last four have only a negative role, as reductions ad absurdum, showing that the existence of all other things is abolished if the One does not exist. He also sees the subjects of Hypotheses II-V represented in the four divisions of the Line in Republic VI (1060.26ff.). But this does not amount to evidence for a commentary. Plutarch's interests, indeed, seem to have run more in the direction of psychology. The two works that he is recorded as reading with Proclus are Aristotle's De Anima and Plato's Phaedo.

Whereas Plutarch pretty certainly communicated his interpretation of the dialogue only orally, the situation with Syrianus is less clear. The fact that Damascius refers to him does not constitute independent evidence of a commentary, since Damascius is only using Proclus. Proclus refers to him repeatedly, but these references may simply be to his own notes of Syrianus' lectures. This is not to say, however, that Syrianus' influence is not paramount in the commentary. Proclus in fact makes no bones about the fact that he owes everything to his master (cf. his remarks in the Preface, 618.3ff. and in Book VI, 1061.20ff.), and the explicit references to him are probably just the tip of the iceberg. The question of Proclus' debt to Syrianus, though generally recognised now by scholars, still needs further exploration through a proper study of Syrianus' own philosophy. Dr. Anne Sheppard has made a useful contribution recently in the matter of the essays on the Republic, ${ }^{20}$ but Syrianus' role in both the Timaeus and Parmenides Commentaries has yet to be fully stated. The more Syrianus emerges from obscurity, the more I think it will become clear that, in Dodds' words, "Proclus is not an innovator, but a systematiser of other men's ideas." 21

Even the extent to which further systematising was required here may be called in question. The basis for Proclus' exegesis of the First and Second Hypotheses is the remarkable notion of Syrianus that each characteristic denied, or asserted, of the One represents a distinct class of gods. A useful table of them is provided by Saffrey and Westerink in the introduction to volume I of the Budé Platonic Theology (pp. lxviiilxix), but it may be worth while reproducing it here, with due acknowledgement:

${ }^{20}$ Studies on the 5th and 6th Essays of Proclus' Commentary on the Republic (Hypomnemata, Heft 61), Göttingen, 1980, ch. 2.

${ }^{21}$ Introduction, p. xxv. 


\begin{tabular}{|c|c|c|c|}
\hline Parmenides & $\begin{array}{l}\text { Attribute } \\
\text { denied }\end{array}$ & Class of gods & In Parmenidem \\
\hline $141 \mathrm{e} 7-142 \mathrm{a} 1$ & One-that-is & intelligible gods & VII, 26K.1-46K.18 \\
\hline $137 c 4-5$ & multiple & $\begin{array}{l}\text { 1st triad of } \\
\text { intelligible- } \\
\text { intellectual gods }\end{array}$ & VI, 1089.17-1097.20 \\
\hline $137 c 4-d 4$ & $\begin{array}{l}\text { whole and } \\
\text { parts }\end{array}$ & $\begin{array}{l}2 \mathrm{~d} \text { triad of } \\
\text { intelligible- } \\
\text { intellectual gods }\end{array}$ & VI, 1097.21-1110.15 \\
\hline $137 \mathrm{~d} 5-138 \mathrm{a} 1$ & shape & $\begin{array}{l}3 \mathrm{~d} \text { triad of } \\
\text { intelligible- } \\
\text { intellectual góds }\end{array}$ & VI, $1110.16-1134.12$ \\
\hline $138 \mathrm{a} 2-\mathrm{b} 7$ & $\begin{array}{l}\text { in itself, } \\
\text { in another }\end{array}$ & $\begin{array}{l}\text { 1st triad of } \\
\text { intellectual gods }\end{array}$ & VII, 1133.13-1152.14 \\
\hline $138 \mathrm{~b} 8-139 \mathrm{~b} 4$ & $\begin{array}{l}\text { at rest, } \\
\text { in motion }\end{array}$ & $\begin{array}{l}2 \mathrm{~d} \text { triad of } \\
\text { intellectual gods }\end{array}$ & VII, 1152.15-1172.26 \\
\hline $139 \mathrm{~b} 5-139 \mathrm{e} 6$ & $\begin{array}{l}\text { the same, } \\
\text { different }\end{array}$ & $\begin{array}{l}\text { 7th divinity } \\
\text { (Demiurge) }\end{array}$ & VII, 1172.27-1191.9 \\
\hline $139 \mathrm{e} 7-140 \mathrm{~b} 5$ & $\begin{array}{l}\text { like, } \\
\text { unlike }\end{array}$ & hypercosmic gods & VII, 1191.10-1201.21 \\
\hline $140 \mathrm{~b} 6-\mathrm{d} 8$ & equal, & encosmic gods & VII, 1201.22-1212.4 \\
\hline $140 \mathrm{e} 1-141 \mathrm{~d} 7$ & time & universal souls & VII, 1212.5-1233.19 \\
\hline $141 \mathrm{~d} 8-\mathrm{e} 7$ & $\begin{array}{l}\text { parts of } \\
\text { time }\end{array}$ & $\begin{array}{l}\text { 'higher beings' } \\
\text { (angels, daemons, } \\
\text { heroes) }\end{array}$ & VII, $1233.20-1239.21$ \\
\hline
\end{tabular}

I have noted these divisions at the appropriate places in the special introductions to Books VI and VII, but it is useful, I think, to have them set out here. This whole scheme is the brainchild of Syrianus, to which Proclus contributes nothing further that is discernible.

The case is pretty certainly the same with the elaborate scheme of ascent through the levels of Form that is discerned in the first part of the dialogue, as expounded throughout Book IV (see the introduction to that book). Proclus presents Parmenides as posing his problems about the Forms simply in order to lead Socrates to a more sophisticated understanding of the multiplicity of levels at which the Forms manifest themselves. Each apparently insoluble puzzle, then, is only insoluble at a certain level. Advance a stage higher, and it solves itself. The Third Man argument, for instance, is an insoluble puzzle at the level of immanent forms, but Parmenides is here leading Socrates to an under- 


\section{GENERAL INTRODUCTION}

standing of transcendent Forms (889.6ff.), where it no longer presents a problem. There are for Proclus no insoluble puzzles in the first part of the Parmenides. But such a scheme, though not attributed at any stage to Syrianus, must surely have formed part of the exegesis of a man who could derive such subtleties as he does from the text of the First Hypothesis.

Like Proclus, Syrianus commented on the whole dialogue, but, as I have said, we cannot be sure that he composed a written commentary. If he did not, then it would indeed be Proclus' chief distinction to have preserved and formalised his master's teachings, here as elsewhere.

\section{THE PLACE OF THE \\ PARMENIDES COMMENTARY IN \\ PROCLUS' WORK}

We know, or think we know, from Marinus, Proclus' biographer, (VP 13), that by the age of 28 (that is to say, by A.D. 440), Proclus had composed ("among many other treatises") his Commentary on the Timaeus. Whether or not Syrianus was still alive at this time is not certain. The date of his death is normally given as about 437 , but on no very conclusive evidence. Proclus' references to him in the Timaeus Commentary are normally in the imperfect ("my own teacher used to say," "the view of my own teacher was"), which is ambiguous since it could simply refer back to Syrianus' views expressed in his seminar, but on the whole it seems more likely that Proclus only began to publish his commentaries after his master's death.

In the Timaeus Commentary, Proclus appears to make reference to a

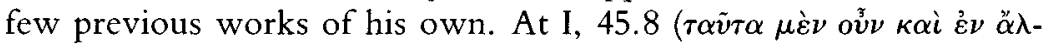

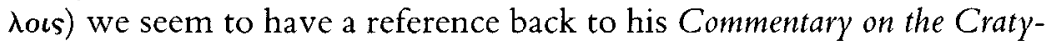
lus (which is preserved in a summary form), where a similar but fuller discussion of the role of the Demiurgic Intellect in the universe is to be found in chapter 99 (48.13-51.13 Pasquali), but this is less than certain. A clearer reference is made to his Commentary on the Philebus (now lost) at I, 385.9 ( $\left.\delta \dot{\varepsilon} \delta \varepsilon \iota \kappa \tau \alpha \iota \delta^{\prime} \dot{\varepsilon} \nu \not \ddot{\alpha} \lambda \lambda o \iota \varsigma\right)$. We also hear of $\sigma v \nu o v \sigma i \alpha \iota$ on the Phaedrus (III, 295.4), which might mean no more than oral lectures, but there seems little point in mentioning them unless they were recorded, and we know from other references (e.g. In Parm. 1128.37, $\dot{\omega} s$ èv $\delta \varepsilon i-$

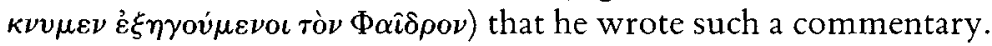

There is evidence, then, that the Timaeus Commentary, while a relatively youthful work, is by no means Proclus' earliest (unless, of course, we assume these references to be later editorial insertions). On the other hand, it is certainly earlier than the Parmenides Commentary. There is an interesting reference forward to the latter at In Tim. III, 